REPORTS OF MORPHOLOGY
Official Journal of the Scientific Society of Anatomists,
Histologists, Embryologists and Topographic Anatomists
of Ukraine
journal homepage: https://morphology-journal.com

\title{
Determination of standard cephalometric parameters using the Downs method for Ukrainian adolescents
}

Dmitriev M.O.

National Pirogov Memorial Medical University, Vinnytsya, Ukraine

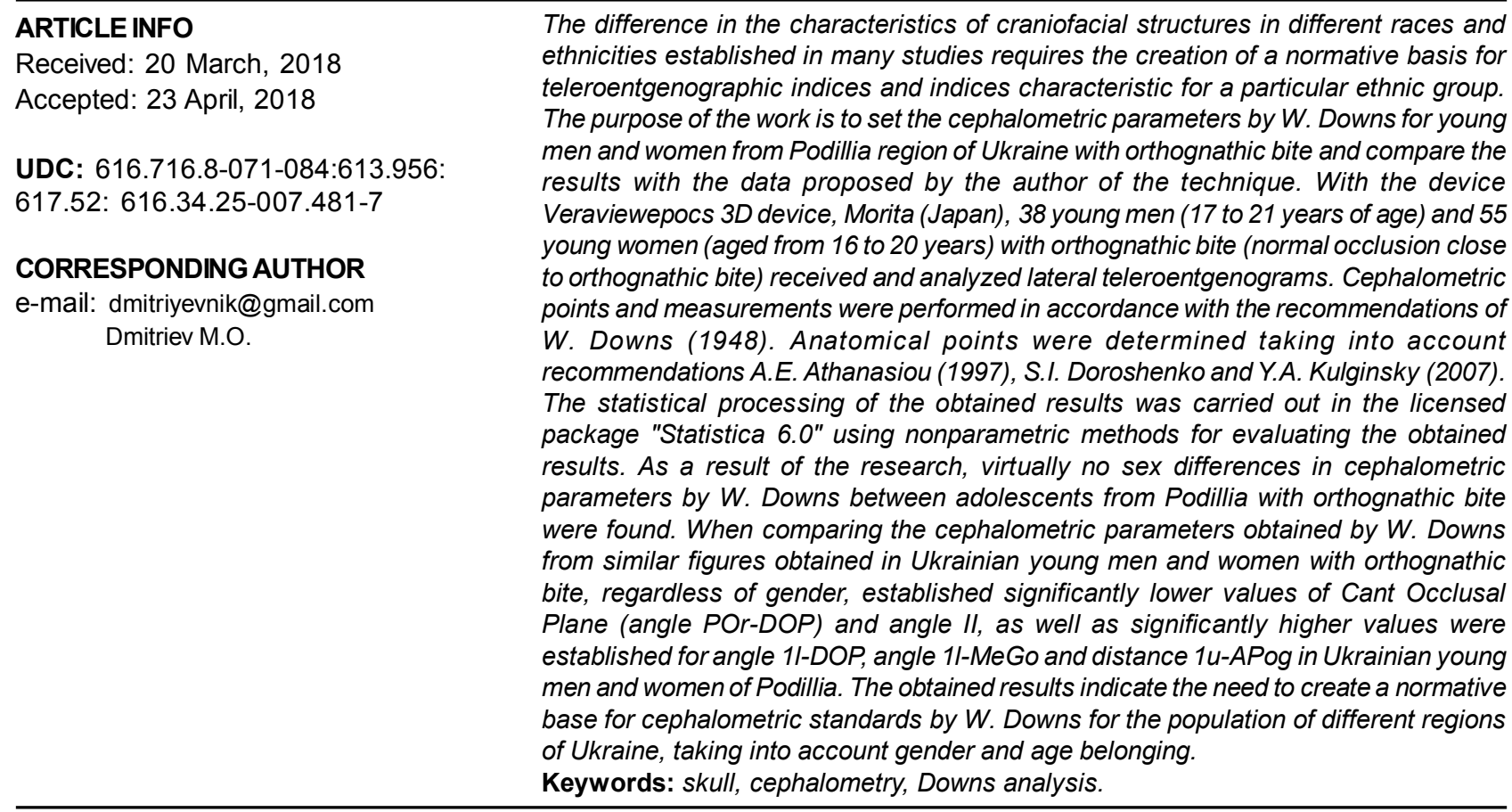

\section{Introduction}

One of the first in 1948, William Downs outlined a technique for cephalometric analysis and recommendations for its clinical application as a result of the study of 10 boys and 10 girls aged from 12 to 17 who had "perfect occlusion" [10]. The proposed method consists of ten indicators that are equally divided into skeletal and dental ones. And for a more easy perception and interpretation of the meanings, a graphic polygon [11] with average values for each indicator and the limits of its deviations was developed. According to R. G. Keim et al. [16] method has gained great popularity and was used from 11.1 to $26.3 \%$ of dental practitioners from 1986 to 2008. The Center for the Study of Human Growth and Development, at the University of Michigan in 1974, for all indicators based on the study of 83 people aged from 6 to
16 years, were defined average standards for each child's age [18]. But it should be borne in mind that the understanding of true occlusion relates to the harmonious features of the person and takes into account the individual ethnic, age and sexual characteristics, which according to various studies vary considerably $[1,4,12,19,20]$.

Since in different races and ethnicities the characteristics of craniofacial structures vary considerably, this situation is not caused by any curiosity of researchers with regard to the study and creation of a normative basis for teleroentgenographic indices and indices characteristic of a particular ethnic group $[3,4,13,17,21]$. As these studies indicate significant variations in the various cephalometric indices, the question arises as to the correctness of the application of normative data obtained in 


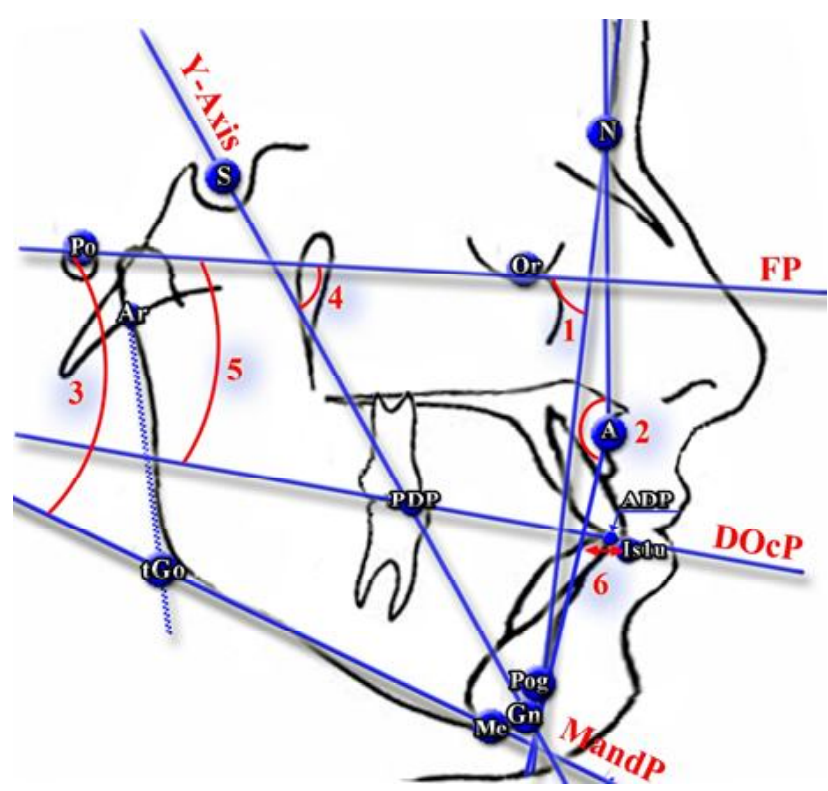

Fig. 1. $\underline{A}$ (subspinale) - point $A$ by Downs, the most posteriorly located point of the anterior contour of the upper jaw; ADP (front locking point by Downs) - middle of vertical incisal overlap between the cutting edges of the middle incisors of the upper and lower jaws, the middle of the vertical and arched gaps between the medial incisors; $\underline{\mathrm{Ar}}$ (articulare) - intersection of the anterior surface of the main part of the occipital bone with the back surface of the cervix of the mandible; $\mathrm{Gn}$ (gnation) - the place of connection of the lower edge of the mandible and the outer contour of the ossified symphysis, the anterior point on the lower contour of the body of the mandible; Is1u (incision superior) -point located on the cutting edge of the upper middle cutter; Me (menton) - the lowest point on the ossified symphysis of the mandible; $\underline{\mathrm{N}}$ (nasion) - the foremost point of the fronto-nasal seam, joints of the frontal and nasal bones in the medialarterial plane; Or (orbitale) - the lowest part of the infraorbital region, is located on the orbital edges of the caudal bone; PDP (posterior Downs point) - middle of the surface of the closure of the near edge of the first upper and lower molar teeth; Po (porion) -placed on the upper edge of the external auditory hole; $\underline{P o g}$ (pogonion) - the most forward point of the bony pectoral projection; $S$ (sella) - constructive point in the center of the Turkish saddle; $\underline{\mathrm{tGo}}$ - the projection point on the angle of the mandible, is formed at the intersection of the lines, one of which is the tangent to the posterior margin of the branch of the mandible from the point Ar, second is the tangent to the lower edge of the body of the mandible from the point Me (usually a few millimeters lower and more distant than a point Go); 1 - angle POr_NPog; 2 - angle of Convexity; 3 - Mandibular PlaneAngle; 4 - YAxis; 5 - Cant of Occlusal Plane; 6 - distance 1u_APog.

the study of another population, for the residents of Ukraine. This calls for further researches.

The purpose of the work - to establish cephalometric parameters by W. Downs in young men and women from Podillia region of Ukraine with orthognathic bite and compare results with the data suggested by the author of the technique.

\section{Materials and methods}

With the device Veraviewepocs 3D device, Morita (Japan), 38 young men (17 to 21 years of age) and 55 young women (aged from 16 to 20 years) with orthognathic occlusion (normal occlusion close to orthognathic bite) received and analyzed lateral teleroentgenograms.

Cephalometric points and measurements were carried out in accordance with the recommendations of $\mathrm{W}$. Downs [10]. Anatomical points were determined taking into account the recommendations of A. E. Athanasiou [2] and S. I. Doroshenko and Y. A. Kulginsky [9].

According to the method of W. B. Downs studied the following indicators (Fig. 1, Fig. 2):

- angle POr_NPog - Facial Depth, angle formed by the reference lines $\underline{\mathrm{Po}} \mathrm{O}-\mathrm{Or}$ and $\mathrm{N}-\mathrm{Pog}$;

- angle NAPog - Angle of Convexity, formed by the reference lines $\underline{N-A}$ and $\underline{A}-P o g$;

- angle AB_NPog - AB Plane Angle, formed by the reference lines $\underline{A-B}$ and $\underline{N-P o g}$ (angle of the plane $\underline{A-B}$, defines the position of the plane $\mathrm{A}-\mathrm{B}$ in relation to the $\mathrm{N}-\mathrm{Pog}$ );

- angle POr_MeGo - Mandibular Plane Angle, angle between the mandibular plane and the Frankfurt Horizontal, formed by the reference lines $\mathrm{Po}$-Or and $\underline{\mathrm{Me}-\mathrm{tGo}}$;

- angle POr_GnS - Y-Axis, determines the cant of the $y$ axis in relationship to the Frankfurt Horizontal, formed by the reference lines $\underline{P-O r}$ and $\underline{S-G n}$;

- angle POr_DOP - Cant of Occlusal Plane, determines the angle of the occlusal plane in relationship to the Frankfurt Horizontal, formed by the reference lines $\underline{\text { Po-Or and ADP- }}$ PDP (occlusal plane);

- angle II - II, angulation of axes of upper to lower incisor, formed by the reference lines Ap1u-ls1L (central axes of the

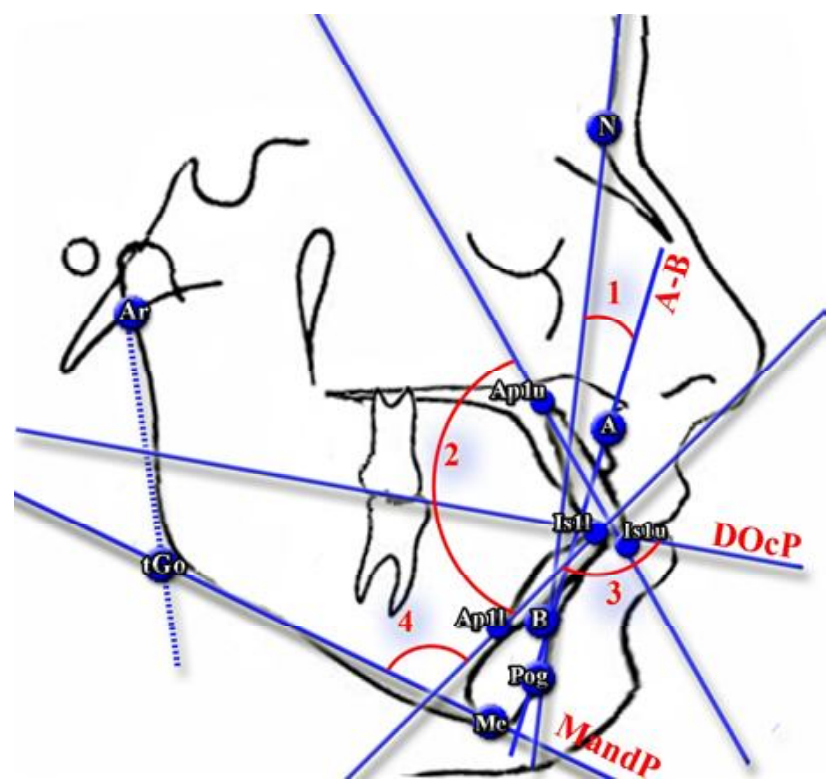

Fig. 2. $\underline{A}$ (subspinale); Ap1L (apex first inferior incisor); Ap1u (apex first upper incisor); $\overline{\mathrm{Ar}}$ (articulare) - intersection of the anterior surface of the main part of the occipital bone with the back surface of the cervix of the mandible; $\underline{B}$ (submentale) - point B by Downs, the deepest point on the anterior contour of the mandible; Is $1 L$ (incision inferior) - point located on the cutting edge of the lower middle cutter; Is1u (incision superior); $\underline{M e}$ (menton); $\underline{\mathrm{N}}$ (nasion); Pog (pogonion); $\underline{\mathrm{tGo}} ; 1$ - AB Plane Angle; 2 - II angle; 3 -Angle 1I_DOP; 4 -Angle 1I_MeGo. 
upper central incisor) and Ap1L-Is1L (central axes of the lower incisor);

- angle 1I_DOP - formed by the reference lines Ap1LIs1L (central axes of the lower incisor) and ADP-PDP (occlusal plane), measures of deviation from the right angle with a positive value in the direction of the clockwise, with a negative if countrclockwise;

- angle 1I_MeGo - Determines the position of the axes of the mandibular incisors (Ap1L-Is1L) in relationship to the mandibular plane (Me-tGo);

- distance 1u_APog - distance from the incisal edge of the most prominent upper incisor $(\underline{\mathrm{Is} 1 \mathrm{u}})$ to the reference line A-Pog.

The statistical processing of the obtained results was carried out in the licensed package "Statistica 6.0" using nonparametric methods for evaluating the obtained results.

\section{Results}

The cephalometric parameters by W. Downs (mean with standard deviation and percentile velocity) in young men and women from Podillia region of Ukraine with orthognathic bite are presented in Table 1.

When comparing cephalometric parameters by $\mathrm{W}$. Downs between young men and women from Podillia region of Ukraine with orthognathic bite, only significantly higher $(p<0.05)$ values of Cant of Occlusal Plane (POr-DOP) were found in young women (see Table 1).

When comparing the cephalometric parameters obtained by $\mathrm{W}$. Downs with the indices obtained in young men and women from Podillia with orthognathic bite, established significantly lower $(p<0.05-0.001)$ values of Cant of Occlusal Plane (angle POr-DOP) and angle II, as well as the tendency ( $p=0.064$ and 0.072$)$ to the lower values of the Y-axis (angle POr-GnS) in Ukrainian young men and women with orthognathic bite (Table 2). Conversely, the value of angle 1I-DOP, angle 1-MeGo and distance 1u-APog in Ukrainian young men and women with orthognathic bite is significantly $(p<0.01-0.001)$ greater than the cephalometric parameters obtained by W. Downs (see Table 2).

\section{Discussion}

When comparing cephalometric parameters used in the Downs analysis between young men and women from Podillia with orthognathic bite, there is practically no gender discrepancy between the values of these indices. Only the value of the indicator of Cant Occlusal Plane (POr-DOP) in young men is significantly higher than that of young women. Since persons with second-degree pathology according to Engle have a more vertically arranged closure plane, and patients with third-degree pathology by Engle have a more horizontal locating plane, this indicator helps to orientate towards the development of the face and determine the person's belonging to one or another groups of anomalies [10]. In previous studies, in the analysis of cephalometric parameters by other methods, we, in contrast to the cephalometric parameters by $W$. Downs, revealed pronounced sexual differences [5-8, 14, 15].

Comparing the cephalometric parameters obtained by $W$. Downs with the magnitude of the data obtained in the young men and women of Podillia with orthognathic bite, we established the pronounced differences only in the dental parameters, namely: significantly lower values of Cant Occlusal Plane (angle POr-DOP) and angle II (which describes both the vertical and horizontal parameters of the closing of the incisors and in clinic, is very important in the consideration of the stable position of the incisors and their operation [10]), and also significantly higher values of the angle 1I-DOP (which allows to estimate the location of the lower incisor to

Table 1. Limits of percentile scope (25p-I -75p-l) teleroentgenographic indicators by the Downs method in Ukrainian boys and girls with orthognathic bite.

\begin{tabular}{|c|c|c|c|c|c|}
\hline \multirow{2}{*}{ Indicators } & \multicolumn{2}{|c|}{ Young men } & \multicolumn{2}{|c|}{ Young women } & \multirow{2}{*}{ p } \\
\hline & $\mathbf{M} \pm \sigma$ & $25 p-1,75 p-I$ & $\mathbf{M} \pm \sigma$ & 25p-I, 75p-I & \\
\hline \multicolumn{6}{|c|}{ Skeleton analysis } \\
\hline POr-NPog $\left({ }^{\circ}\right)$ & $89.25 \pm 3.26$ & $86.6-91.0$ & $88.57 \pm 2.91$ & $86.5-90.6$ & $>0,05$ \\
\hline NAPog $\left({ }^{\circ}\right)$ & $1.388 \pm 4.786$ & $-2.3-5.3$ & $0.996 \pm 5.077$ & $-2.6-4.3$ & $>0,05$ \\
\hline AB-NPog $\left({ }^{\circ}\right)$ & $-4.772 \pm 2.979$ & $-6.3--2.6$ & $-4.135 \pm 2.912$ & $-5.9--2.3$ & $>0,05$ \\
\hline POr-MeGo $\left({ }^{\circ}\right)$ & $19.95 \pm 6.23$ & $16.1-24.1$ & $21.89 \pm 4.44$ & $18.4-24.1$ & $>0,05$ \\
\hline POr-GnS ( $\left.{ }^{\circ}\right)$ & $57.64 \pm 3.85$ & $56.2-59.9$ & $58.02 \pm 3.06$ & $56.5-60.4$ & $>0,05$ \\
\hline \multicolumn{6}{|c|}{ Dental analysis } \\
\hline POr-DOP ( $\left.{ }^{\circ}\right)$ & $5.350 \pm 3.779$ & $2.6-7.5$ & $7.264 \pm 3.727$ & $4.8-9.9$ & $<0,05$ \\
\hline$\|\left(1\left(^{\circ}\right)\right.$ & $130.6 \pm 7.1$ & $126.0-134.9$ & $130.5 \pm 8.0$ & $125.4-135.5$ & $>0,05$ \\
\hline 11-DOP $\left({ }^{\circ}\right)$ & $21.67 \pm 5.69$ & $18.1-25.8$ & $19.69 \pm 6.52$ & $15.5-24.5$ & $>0,05$ \\
\hline 11-MeGo $\left({ }^{\circ}\right)$ & $7.063 \pm 8.082$ & $0.5-13.2$ & $5.073 \pm 6.492$ & $-1.1-9.6$ & $>0,05$ \\
\hline 1urAPog (mm) & $4.889 \pm 1.609$ & $4.0-5.8$ & $4.553 \pm 1.902$ & $3.2-5.8$ & $>0,05$ \\
\hline
\end{tabular}

Notes: $\mathrm{M} \pm \sigma$ - average \pm standard deviation; $\mathrm{p}$ - the reliability of sizes differences between young men and women. 
Table 2. Comparison of teleroentgenographic indicators obtained by $W$. Downs with Ukrainian young men and women with orthognathic bite $(\mathrm{M} \pm \sigma)$.

\begin{tabular}{|c|c|c|c|}
\hline Indi & Downs value & You & You \\
\hline \multicolumn{4}{|c|}{ Skeleton analysis } \\
\hline POr-NPog $\left(^{\circ}\right)$ & $87.8 \pm 3.57$ & $89.25 \pm 3.26$ & $88.57 \pm 2.91$ \\
\hline NAPog $\left({ }^{\circ}\right)$ & $0.0 \pm 5.09$ & $1.388 \pm 4.786$ & $0.996 \pm 5.077$ \\
\hline AB-NPog $\left({ }^{\circ}\right)$ & $-4.6 \pm 3.67$ & $-4.772 \pm 2.979$ & $-4.135 \pm 2.912$ \\
\hline POr-MeGo $\left({ }^{\circ}\right)$ & $21.9 \pm 3.24$ & $19.95 \pm 6.23$ & $21.89 \pm 4.44$ \\
\hline POr-GnS ( $\left.{ }^{\circ}\right)$ & $59.4 \pm 3.82$ & $57.64 \pm 3.85 \mathrm{t}$ & $58.02 \pm 3.06 \mathrm{t}$ \\
\hline \multicolumn{4}{|c|}{ Dental analysis } \\
\hline POr-DOP $\left({ }^{\circ}\right)$ & $9.3 \pm 3.83$ & $5.350 \pm 3.779 * * *$ & $7.264 \pm 3.727$ * \\
\hline II $\left({ }^{\circ}\right)$ & $135.4 \pm 5.76$ & $130.6 \pm 7.1$ ** & $130.5 \pm 8.0$ ** \\
\hline 11-DOP $\left({ }^{\circ}\right)$ & $14.5 \pm 3.48$ & $21.67 \pm 5.69$ *** & $19.69 \pm 6.52$ *** \\
\hline 11-MeGo $\left({ }^{\circ}\right)$ & $1.4 \pm 3.78$ & $7.063 \pm 8.082$ *** & $5.073 \pm 6.492$ ** \\
\hline 1u-APog (mm) & $2.7 \pm 3,05$ & $4.889 \pm 1.609 * * *$ & $4.553 \pm 1.902$ *** \\
\hline \multicolumn{4}{|c|}{$\begin{array}{l}\text { Notes: }{ }^{*},{ }^{* *},{ }^{* * *}-\text { significant differences }(p<0.05, p<0.01 \text { and } \\
p<0.001) \text { of corresponding indicators obtained by W. Downs method } \\
\text { with young men and women from Podillia region of Ukraine with } \\
\text { orthognathic bite; } t-\text { trends differences of corresponding indicators } \\
\text { obtained by W. Downs method with young men and women from } \\
\text { Podillia region of Ukraine with orthognathic bite. }\end{array}$} \\
\hline
\end{tabular}

the functional plane, and since the mandibular plane has large fluctuations, especially in terminal skeletal profiles, the definition of this indicator is very useful in treating and evaluating the index of the position of the lower incisor in relation to the mandibular plane [10]), angle 1/-MeGo (which clinically helps to determine the position of the lower median incisors not in relation to the facial planes, to which the lower jaw may be located in different positions, namely to the anatomical structure in which it is located [10]) and distance $1 \mathrm{u}$-APog (which is used as a measure of evaluation of maxillary denture protrusion and allows in millimeters to define and interpret the position of the incisors in the sagittal plane [10]) in Ukrainian young men and women with orthognathic bite. Among the skeletal indicators, only the tendency towards

\section{References}

[1] Alam, M. K., Basri, R., Kathiravan, P., Sikder, M., Saifuddin, M., \& lida, J. (2012). Cephalometric evaluation for Bangladeshi adult by Down's analysis. International Medical Journal, 19(3), 258-261.

[2] Athanasiou, A. E. (1997). Orthodontic cephalometry. London. Osby Wolfe.

[3]Atit, M. B., Deshmukh, S. V., Rahalkar, J., Subramanian, V., Naik, C., \& Darda, M. (2013). Mean values of Steiner, Tweed, Ricketts and McNamara analysis in Maratha ethnic population: A cephalometric study. APOS Trends in Orthodontics, 3(51), 137-151. doi: 10.4103/2321-1407.119095

[4] Celebi, A. A., Tan, E., Gelgor, I. E., Colak, T., \& Ayyildiz, E. (2013). Comparison of Soft Tissue Cephalometric Norms between Turkish and European-American Adults. The Scientific World Journal, 2013:806203. http://dx.doi.org/10.1155/2013/806203

[5] Dmitriev, M. O. (2017). Identification of normative cephalometric parameters based on $\mathrm{G}$. Schmuth method for young male and female Ukrainians. Reports of morphology, 23(2), 288-292.

[6] Dmitriev, M. O., Chugu, T. V., Gerasymchuk, V. V., \& Cherkasova, the lower values of the Y-Axis (angle POr-GnS) in Ukrainian young men and women with orthognathic bite is established.

It should be noted that according to our research, most of the cephalometric parameters obtained in Podillia young men and women with orthognathic bite didn't have significant differences with the data of the parameters obtained by $G$. Shmut [5], C. Stiner [8] and A.M. Schwartz [6]. Numerous differences in the cephalometric parameters used in Charles $\mathrm{H}$. Tweed International Foundation analysis with the results obtained in Ukrainian young men and women with orthognathic bite have been set for angles (regardless of sex, the smaller angles of FMA and POr_OcP and larger IMRA angles values), so and for linear dimensions (larger PFH distances for young men and smaller AFH distances for young women and $\mathrm{AFH}$ _PFH ratios for young men and women) [15], as well as almost half of the cephalometric parameters obtained in young men and women from Podillia with orthognathic bite with marked differences in the magnitude of these parameters derived by J. McNamara [14].

The results obtained by us indicate the need to establish a normative base for cephalometric norms by W. Downs for the population of different regions of Ukraine, taking into account gender and age belongings.

\section{Conclusion}

1. In the analysis of sexual differences of cephalometric parameters by $W$. Downs between young men and women of Podillia with orthognathic bite, only significantly higher values of the indicator of Cant of Occlusal Plane (POr-DOP) in young men were established.

2. Differences in the cephalometric parameters obtained by $W$. Downs from the indices obtained in young men and women from Podillia with orthognathic bite are set independently from the gender mainly for dental indicators: significantly less values of Cant Occlusal Plane (angle POrDOP) and angle II, as well as the values of angle 1I-DOP, angle 1I-MeGo and distance $1 \mathrm{u}-\mathrm{APog}$ are significantly higher in Podillia young men and women.

O. V. (2017). Determination of craniometric and gnatometric indicators by A.M. Schvartz method for Ukrainian boys and girls. Biomedical and Biosocial Anthropology, 29, 53-58.

[7] Dmitriev, M. O., Tikholaz, V. O., Shepitko, K. V., ShinkarukDykovytska, M. M., Androshchuk, O. V., Bobruk, S. V., \& Zakalata, T. R. (2018). Sexual dimorphism of normative cephalometric parameters determined by the Holdaway method in boys and girls of Podillia. World of Medicine and Biology, 2(64), 39-43. doi: 10.26.724/2079-8334-2018-2-64-39-43

[8] Dmitriev, N. A. (2016). Definition of normative cephalometric parameters by Steiner method for Ukrainian young men and women. World of Medicine and Biology, 3(57), 28-32.

[9] Doroshenko, S. I., \& Kulginskiy, E. A. (2007). Teleroentgenography Basics. K.: Zdorov'ya.

[10] Downs, W. B. (1948). Variation in facial relationships, their significance in treatment and prognosis. Am. J. Orthod., 34, 812-840.

[11] Downs, W. B. (1956). Analysis of the dentofacial profile. Angle 
Orthodontist, 26, 191-212.

[12] Ghorbany Javadpour, F., \& Khanemasjedi, M. (2014). Soft tissue facial profile and anteroposterior lip positioning in Iranians. Journal of Dental School, 32(2), 90-95.

[13] Gonzalez, M. B., Caruso, J. M., Sugiyama, R. M., \& Schlenker, W. L. (2013). Establishing cephalometric norms for a Mexican population using Ricketts, Steiner, Tweed and Arnett analyses. APOS Trends Orthod., 3, 171-177. doi: 10.4103/23211407.121437

[14] Gunas, I. V., Dmitriev, M. O., Tikholaz, V. O., ShinkarukDykovytska, M. M., Pastukhova, V. A., Melnik, M. P., \& Rudiy, Yu. I. (2018). Determination of normal cephalometric parameters by J. McNamara method for Ukrainian boys and girls. World of Medicine and Biology, 1(63), 19-22. doi: 10.26.724/2079-8334-2018-1-63-19-22

[15] Gunas, I. V., Dmitriev, M. O., Prokopenko, S. V., ShinkarukDykovytska, M. M., \& Yeroshenko, G. A. (2017). Determination regulatory cephalometric options by the method of Tweed International Foundation for Ukrainian boys and girls. World of Medicine and Biology, 4(62), 27-31. doi: 10.26.724/2079-83342017-4-62-27-31
[16] Keim, R. G., Gottlieb, E. L., Nelson, A. H., \& Vogels, D. S. (2008). JCO study of orthodontic diagnosis and treatment procedures, part 1: results and trends. J. Clin. Orthod., 42(11), 625-640. PMID: 25416338

[17] Rajbhandari, A. (2011). Tweed's diagnostic facial triangle for nepalese adults. Orthodontic Journal of Nepal, 1(1), 11-15. doi: http://dx.doi.org/10.3126/ojn.v1i1.9359

[18] Riolo, M. L. (1974). An Atlas of craniofacial growth : cephalometric standards from the University school growth study, the University of Michigan. Ann Arbor, Mich.: Center for Human Growth and Development, University of Michigan.

[19] Shafi, A. M., Khan, F. N., Khan, A.G., Nadeem, M., Khursheed, T., \& Jehan, S. (2018). A Soft Tissue Cephalometric Analysis for Pakistani Adult Using Holdaway's Analysis. International Medical Journal, 25(1), 51-53.

[20] Solmaz, I., \& Raberin, M. (2011). Is the ethnic factor an orthodontic therapeutic instructor. Orthod. Fr., 82(4), 347358. doi: $10.1051 /$ orthodfr/2011143

[21] Zawawi, K. H. (2012). Comparison of Wits appraisal among different ethnic groups. J. Orthod. Sci., 1(4), 88-91. doi: 10.4103/2278-0203.105874

\section{ВИЗНАЧЕННЯ НОРМАТИВНИХ ЦЕФАЛОМЕТРИЧНИХ ПАРАМЕТРІВ МЕТОДОМ W.DOWNS ДЛЯ УКРАÏНСЬКИХ ЮНАКІВ । ДІВЧАТ \\ Дмітрієе м.O.}

Встановлена в багатьох дослідженнях відмінність характеристик краніофаціальних структур у різних рас та етносів вимагає створення нормативної бази для телерентгенографічних показників та індексів, характерних для певної етнічної групи. Ціль роботи - встановити иефралометричні параметри за W. Downs у юнаків і дівчат Подільського регіону України з ортогнатичним прикусом і порівняти результати з даними, що запропоновані автором методики. За допомогою пристрою Veraviewepocs 3D, Morita (Японія), у 38 юнаків (віком від 17 до 21 року) та 55 дівчат (віком від 16 до 20 років) з ортогнатичним прикусом (нормальною оклюзією наближеною до ортогнатичного прикусу) були отримані та проаналізовані бокові телерентаенограми. Цефралометричні точки і вимірювання були проведені заідно з рекомендаціями W. Dоwns (1948). Анатомічні точки визначали з урахуванням рекомендацій A.E. Athanasiou (1997), C.I. Дорошенко та Є.A. Кульгинского (2007). Статистична обробка отриманих результатів проведена в ліцензійному пакеті "Statistica 6,0" з використанням непараметричних методів оцінки отриманих результатів. В результаті проведених досліджень практично не виявлено статевих розбіжностей цефралометричних параметрів за W. Downs між юнаками та дівчатами Поділля з ортогнатичним прикусом. При порівнянні цефралометричних параметрів, що отримані W. Downs від аналогічних показників, що отримані в українських юнаків $і$ дівчат з ортогнатичним прикусом незалежно від статі, встановлені достовірно менші значення нахилу оклюзійної площини (кут POr-DOP) та кута II, а також достовірно більші значення величини кута 11-DOP, кута 11-МеGо та відстані 1u-APog в юнаків і дівчат Поділля. Отримані результати вказують на необхідність створення нормативної бази цефралометричних нормативів за W. Downs для населення різних регіонів України з урахуванням статевої та вікової належності.

Ключові слова: череп, цефалометрія, аналіз Downs.

\section{ОПРЕДЕЛЕНИЕ НОРМАТИВНЫХ ЦЕФАЛОМЕТРИЧЕСКИХ ПАРАМЕТРОВ МЕТОДОМ W.DOWNS ДЛЯ УКРАИНСКИХ ЮНОШЕЙ И ДЕВУШЕК \\ Дмитриев Н. А.}

Установленное во многих исследованиях различие характеристик краниофациальных структур в различных рас и этносов требует создания нормативной базы для телерентгенографических показателей и индексов характерных для определенной этнической группы. Цель работы - установить цефралометрические параметры по W. Downs у юношей и девушек Подольского региона Украины с ортогнатическим прикусом и сравнить результаты с данными, предложенные автором методики. C помощью устройства Veraviewepocs 3D, Моrita (Япония), у 38 юношей (в возрасте от 17 до 21 года) и 55 девочек (в возрасте om 16 до 20 лет) с ортогнатическим прикусом (нормальной окклюзией приближенной к ортогнатическому прикусу) были получены и проанализированы боковые телерентгенограммы. Цефралометрические точки и измерения были проведены в coответствии с рекомендациями W. Downs (1948). Анатомические точки определяли с учетом рекомендаций A.E. Athanasiou (1997), С.И. Дорошенко и Е.А. Кульгинского (2007). Статистическая обработка полученных результатов проведена в лицензионном пакете "Statistica 6,0" с использованием непараметрических методов оценки полученных результатов. В результате проведенных исследований практически не обнаружено половых различий цефралометрических параметров по W. Downs между юношами и девушками Подолья с ортогнатическим прикусом. При сравнении цефалометрических параметров, полученные W. Downs om аналогичных показателей, полученных от украинских юношей и девушек с ортогнатическим прикусом независимо от пола, установлены достоверно меньшие значения наклона окклюзионной плоскости (угол POr-DOP) и угла II, a также достоверно большие значения величины угла 11-DOP, угла 11-MeGo и расстояния 1u-AРоg у юношей и девушек Подолья. Полученные результаты указывают на необходимость создания нормативной базы цефалометрических нормативов по W. Downs для населения различных регионов Украины с учетом половой и возрастной принадлежности.

Ключевые слова: череп, цефралометрия, анализ Downs. 